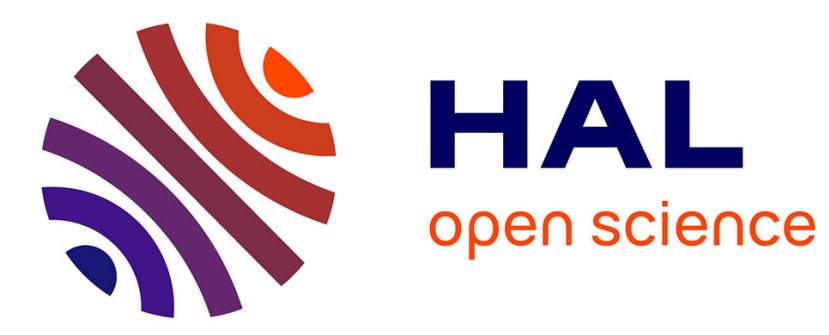

\title{
Significance of floods in metal dynamics and export in a small agricultural catchment
}

\author{
Vincent Roussiez, Anne Probst, Jean-Luc Probst
}

\section{To cite this version:}

Vincent Roussiez, Anne Probst, Jean-Luc Probst. Significance of floods in metal dynamics and export in a small agricultural catchment. Journal of Hydrology, 2013, vol. 499, pp. 71-81. 10.1016/j.jhydrol.2013.06.013 . hal-00906410

\section{HAL Id: hal-00906410 https://hal.science/hal-00906410}

Submitted on 19 Nov 2013

HAL is a multi-disciplinary open access archive for the deposit and dissemination of scientific research documents, whether they are published or not. The documents may come from teaching and research institutions in France or abroad, or from public or private research centers.
L'archive ouverte pluridisciplinaire HAL, est destinée au dépôt et à la diffusion de documents scientifiques de niveau recherche, publiés ou non, émanant des établissements d'enseignement et de recherche français ou étrangers, des laboratoires publics ou privés. 


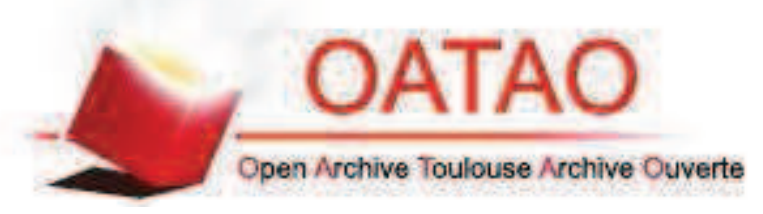

\section{Open Archive TOULOUSE Archive Ouverte (OATAO)}

OATAO is an open access repository that collects the work of Toulouse researchers and makes it freely available over the web where possible.

This is an author-deposited version published in : http://oatao.univ-toulouse.fr/ Eprints ID : 9960

To link to this article : DOI : 10.1016/j.jhydrol.2013.06.013

URL : http://dx.doi.org/10.1016/j.jhydrol.2013.06.013

To cite this version : Roussiez, Vincent and Probst, Anne and Probst, Jean-Luc Significance of floods in metal dynamics and export in a small agricultural catchment. (2013) Journal of Hydrology, vol. 499 . pp. 71-81. ISSN 0022-1694

Any correspondance concerning this service should be sent to the repository administrator: staff-oatao@,listes-diff.inp-toulouse.fr 


\title{
Significance of floods in metal dynamics and export in a small agricultural catchment
}

\author{
Vincent Roussiez ${ }^{\mathrm{a}, \mathrm{b}}$, Anne Probst ${ }^{\mathrm{a}, \mathrm{b}, *}$, Jean-Luc Probst ${ }^{\mathrm{a}, \mathrm{b}}$ \\ ${ }^{a}$ Université de Toulouse; INPT, UPS; Laboratoire Ecologie Fonctionnelle et Environnement (EcoLab); ENSAT, 31326 Castanet Tolosan, France \\ ${ }^{b}$ CNRS; EcoLab; ENSAT, 31326 Castanet Tolosan, France
}

Keywords:

Agricultural catchment

Trace metal dynamics

Trace metal fluxes

Flash-flood

Environmental impact

Metal fractionation

\begin{abstract}
S U M M A R Y
High-resolution monitoring of water discharge and water sampling were performed between early October 2006 and late September 2007 in the Montoussé River, a permanent stream draining an experimental agricultural catchment in Gascogne region (SW France). Dissolved and particulate concentrations of major elements and trace metals (i.e. $\mathrm{Al}, \mathrm{Fe}, \mathrm{Mn}, \mathrm{As}, \mathrm{Cd}, \mathrm{Cr}, \mathrm{Cu}, \mathrm{Ni}, \mathrm{Pb}, \mathrm{Sc}$ and $\mathrm{Zn}$ ) were examined. Our results showed that contamination levels were deficient to moderate, as a result of sustainable agricultural practices. Regarding dynamics, metal partitioning between particulate and dissolved phases was altered during flood conditions: the particulate phase was diluted by coarser and less contaminated particles from river bottom and banks, whereas the liquid phase was rapidly enriched owing to desorption mechanisms. Soluble/reactive elements were washed-off from soils at the beginning of the rain episode. The contribution of the flood event of May 2007 (by far the most significant episode over the study period) to the annual metal export was considerable for particulate forms (72-82\%) and moderate for dissolved elements (0-20\%). The hydrological functioning of the Montoussé stream poses dual threat on ecosystems, the consequences of which differ from both temporal and spatial scales: (i) desorption processes at the beginning of floods induce locally a rapid enrichment (up to 3.4-fold the pre-flood signatures on average for the event of May 2007) of waters in bioavailable metals, and (ii) labile metals - enriched by anthropogenic sources - associated to particles (mainly via carbonates and Fe/Mn oxides), were predominantly transferred during floods into downstream-connected rivers.
\end{abstract}

\section{Introduction}

Naturally occurring in the earth's crust, trace metals are emitted by human activities (industry, mining, agriculture, cities...) and accumulate in the different compartments of the hydrosphere (Adriano, 2001), both in dissolved and particulate forms. Soils constitute the first repository areas, receiving most of the influx via atmospheric deposition, urban runoff, wastewater, industrial effluents and agricultural practices (Nicholson et al., 2003). Part of them may be available for plants and finally contaminate the food chain, exposing humans to elevated health risks (Oliver, 1997). In the meantime, anthropogenic metals sequestrated in soils during the dry season can episodically be washed-off during rain episodes and flushed to the river, particularly when runoff is important. Their ultimate fate in downstream-connected hydrosystems depends mainly on their form (Sparks, 1995; Jiang et al., 2011). Metals have natural affinities for particles, especially under neutral $\mathrm{pH}$

\footnotetext{
* Corresponding author at: Université de Toulouse; INPT, UPS; Laboratoire Ecologie Fonctionnelle et Environnement (EcoLab); ENSAT, 31326 Castanet Tolosan, France.
}

E-mail address: anne.probst@ensat.fr (A. Probst). conditions, so that the major part of the river-transported metals is generally associated with suspended particulate matter. However, changes in physico-chemical conditions ( $\mathrm{pH}$, redox...) encountered during transport can cause their mobilization in the dissolved phase (e.g. Zwolsman et al., 1997; Elbaz-Poulichet et al., 2001, Brunel et al., 2003, Gundersn and Steinnes, 2003), where they become easily bioavailable. Determining the time and space scales over which these solid-phase metals are desorbed remains a critical factor in evaluating their bioavailability. It is fundamental, therefore, that the riverine transport pathways are well documented and that fluxes of metals are accurately estimated. These requirements can be met with an adequate sampling frequency (Syvitski and Morehead, 1999), especially in heterogeneous, small or medium scale watersheds, where discharge regimes and geochemical parameters are highly variable (Coynel et al., 2007).

To determine the key processes of metal transfer, partitioning and bioavailability, most efforts of researchers have focused on large-size river basins (e.g. Audry et al., 2004; Gaeiro et al., 2003; Ollivier et al., 2011) and estuary/coastal areas (e.g. Zhang, 1999; Roussiez et al., 2011, 2012), due to ever-increasing numbers of people living there and growing anthropogenic pressure on ecosystems. Conversely, little attention has been paid regarding 
small-scale and low population density catchments devoted to agricultural activities, especially on calcareous lands. To increase their crop production and make culture possible in nutrient-deficient lands, farmers commonly use a broad suite of fertilizers and pesticides. These products include a variable proportion of metals such as $\mathrm{Cd}, \mathrm{Cr}, \mathrm{Cu}, \mathrm{Ni}, \mathrm{Pb}$ and $\mathrm{Zn}$ as constituents or impurities (Nicholson et al., 2003). To reduce the risks of environmental and ecological damages, strategies have emerged to reconcile agricultural methods with the principles of sustainable development.

The Montoussé catchment is a small and minimally populated agricultural river basin in the Gascogne region (Southwestern France), with rotation of wheat and sunflower crops. In collaboration with the research laboratories in Toulouse and the GPN society (initially "Société Chimique de la Grande Paroisse"), farmers of the Montoussé catchment have developed over the last two decades a production strategy that fulfills the concept of integrated farming. This area represents therefore a suitable long-term observatory belonging to the French catchment observatory network (RBV). It is driven by EcoLab for measuring both the effectiveness and the benefits of such management practices in terms of contaminant export. In this context, the riverine fluxes of $\mathrm{Al}, \mathrm{Fe}, \mathrm{Mn}, \mathrm{As}, \mathrm{Cd}$, $\mathrm{Cr}, \mathrm{Cu}, \mathrm{Ni}, \mathrm{Pb}, \mathrm{Sc}$ and $\mathrm{Zn}$, both dissolved and particulate, have been reconstructed at the outlet of the Montoussé stream, over a oneyear survey (October 2006 - September 2007), with a special emphasis on the environmental/ecological implications. Attention was focused on the significance of the discharge regime in metal yields and the accuracy of their estimates.

\section{Materials and methods}

\subsection{Study area}

The characteristics of the study area are fully described in Perrin et al. (2008) and Ferrant et al. (2012). Briefly, the Montoussé river basin (328 ha) is located $35 \mathrm{~km}$ west of the city of Toulouse (South- western France, see Fig. 1) and lies on a shallow calcareous substratum, which is relatively impermeable owing to its high abundance in clays. Consequently, the discharge of the Montoussé stream is mainly supplied by surface and sub-surface run-off. The thickness of alluvium varies from few $\mathrm{cm}$ in the overhanging formations (where Oligo-Miocene molassic deposits - called molasses - nearly outcrops) to a few meters in the lowest zones. The difference in soil elevation between plateau relics and outlet is $100 \mathrm{~m}$.

The hydrological regime is mainly pluvial regulated by rainfall (see also Section 2.3), with a wet period running from October to May. Similar to the other rivers in the Gascogne region, the Montoussé stream undergoes very important inter-annual variations (Probst and Tardy, 1985). Although very small during summer (especially between July and August), the stream is permanent and feeds the Boulouze River, which itself opens into the Save River, i.e. one of the 3 main left-bank tributaries of the Garonne River (647 km length from Spanish Pyrenees to the Gironde estuary in France) draining the Gascogne region (Fig. 1). Importantly for our investigation on trace metals, the waters of Montoussé stream are neutral to alkaline (pH recorded between 2004 and 2006 exhibit a mean value of 8.1, according to Perrin et al., 2008). Calcium and alkalinity $\left(\mathrm{HCO}_{3}^{-}\right)$are the major ions.

The river basin is characterized by low population density (29 inhab. $/ \mathrm{km}^{2}$ ) and exclusively devoted to agricultural activities: ca. $86 \%$ of land cover is wheat and sunflower cultures with cropping management, with the remaining in pasture/grass areas (ca. $5 \%$ ), woods (ca. 5\%) and habitations (ca. $4 \%$ ). Some general characteristics of the watershed are summarized in Table 1. Note that the annual rainfall measured for the study period (i.e. $640 \mathrm{~mm}$ between October 2006 and September 2007) is in line with the average for the last 20 years (i.e. $656 \mathrm{~mm}$, Ferrant et al., 2012). The specific solid discharge of the Montoussé stream estimated in this study at $33.5( \pm 7.2) \mathrm{t} \mathrm{km}^{-2} \mathrm{yr}^{-1}$ is in agreement with the value (i.e. $27 \mathrm{t} \mathrm{km}^{-2} \mathrm{yr}^{-1}$ ) given by Probst (1986) for the nearby Girou River, a right-bank tributary of the Garonne River draining a homogeneous

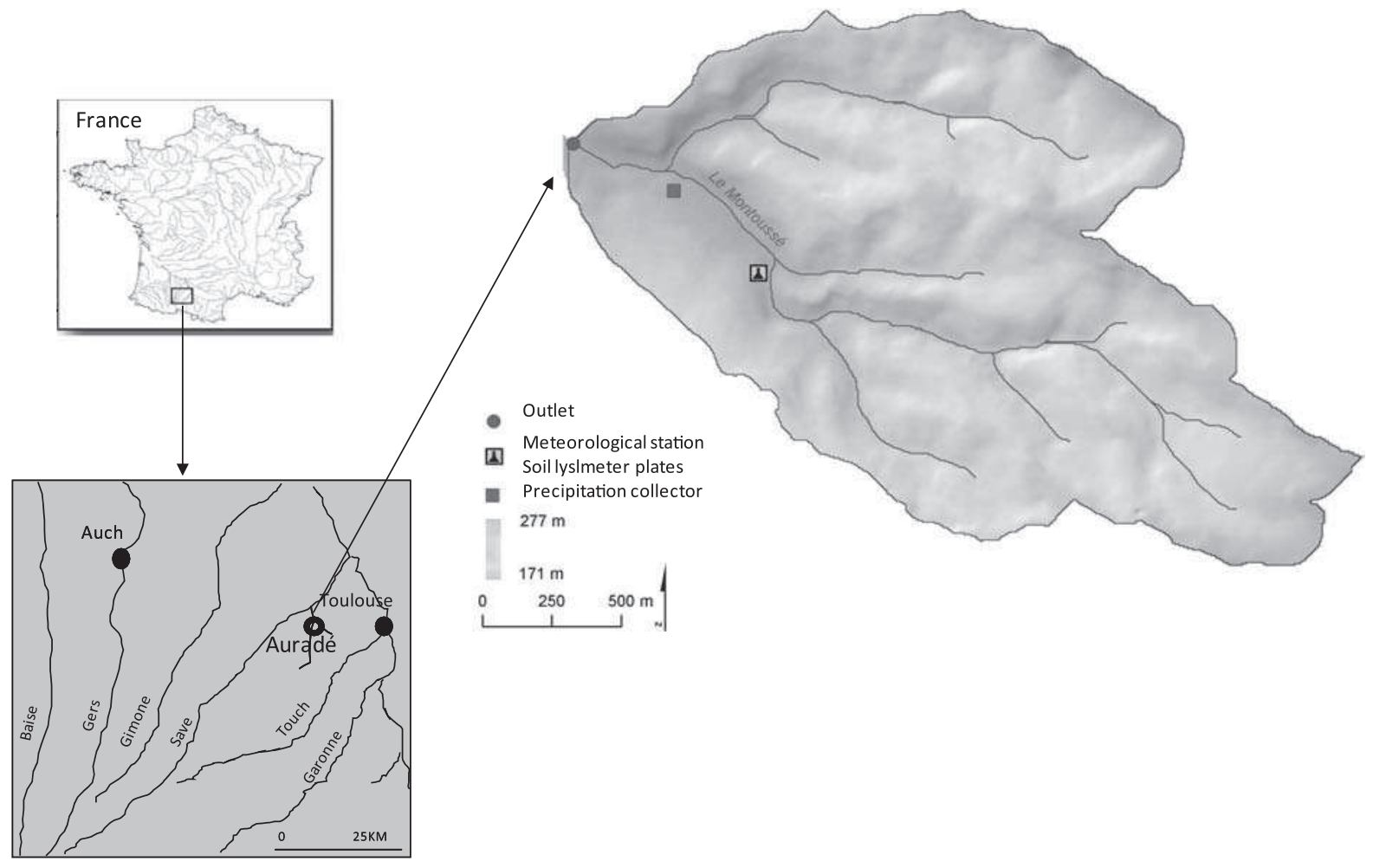

Fig. 1. Geographical location of the study area. 
Table 1

General characteristics of the Montoussé experimental catchment.

\begin{tabular}{ll}
\hline & Montoussé catchment \\
\hline Surface area $\left(\mathrm{km}^{2}\right)$ & 3.28 \\
Annual rainfall $(\mathrm{mm})^{\mathrm{a}}$ & 640 \\
Annual water discharge $\left(\mathrm{m}^{3} / \mathrm{mm}\right)^{\mathrm{a}}$ & $214,000 / 65$ \\
Specific water discharge $\left(\mathrm{L} \mathrm{s}^{-1} \mathrm{~km}^{-2}\right)^{\mathrm{a}}$ & 2.10 \\
Annual SPM discharge $(\mathrm{t})^{\mathrm{a}}$ & $109.9( \pm 23.7)$ \\
Specific SPM discharge $\left(\mathrm{t} \mathrm{km}^{-2} \mathrm{yr}^{-1}\right)^{\mathrm{a}}$ & $33.5( \pm 7.2)$ \\
Land use cover $(\%)$ & \\
Cropland & 86 \\
Pasture/grass bands & 5 \\
Woods & 5 \\
Habitations & 4
\end{tabular}

${ }^{\text {a }}$ Measured/estimated for the study period, i.e. from late September 2006 to early October 2007. SPM: Suspended particulate matter. Comparison between annual rainfall and annual water discharge $(\mathrm{mm})$ gives evidence that evapotranspiration and/or aquifer recharge are important sinks for precipitation in this catchment.

agricultural catchment of $520 \mathrm{~km}^{2}$, also covered by Oligocene molassic deposits.

\subsection{Sample collection, analytical procedures and monitoring}

Water samples were collected at the outlet of the Montoussé stream between October 2006 and September 2007, by automatic ISCO 3700 (Lincoln, USA) and ECOTECH AWS2002 (Bohn, Germany) samplers. The former collected samples with a 24-h interval while the second was programmed to activate pumping water on the basis of water level variations (each $3 \mathrm{~cm}$ in this study) recorded by a pressure probe installed on an YSI 6920 EDS multi-parameter sensor. Samples were collected into polypropylene bottles specifically designed to fit the samplers and pre-cleaned with $1 \mathrm{~N} \mathrm{HCl}$. Samples were recovered each week or following a flood episode when occurring. Returned to the laboratory, samples were filtered immediately by $1 \mathrm{~N} \mathrm{HCl}$ precleaned Nalgene filtration systems, using cellulose acetate filters of $0.22 \mu \mathrm{m}$ pore size and $45 \mathrm{~mm}$ diameter. Prior to filtration, each filter was pre-weighed and rinsed with $500 \mathrm{ml}$ of Milli-Q water. Filtered waters were acidified to $\mathrm{pH} 1$ by suprapure nitric acid before being stored at $4{ }^{\circ} \mathrm{C}$ until analyses. Filters were dried overnight at $50{ }^{\circ} \mathrm{C}$ in a clean oven and stored in hermetic boxes at $4{ }^{\circ} \mathrm{C}$ until analyses. Suspended particulate matter content was calculated from dry weight difference.

Metal and rare earth element (REE) analyses were performed by Inductively Coupled Plasma - Mass Spectrometer (ICP-MS) at the OMP-GET (Observatoire Midi-Pyrénées - Laboratoire Géosciences Environnement, Toulouse) analytical platform. Seventy-two samples were selected and analysed for dissolved metals and 53 for total particulate metals and REE. Filters for particulate analyses were totally digested by a $\mathrm{HF}-\mathrm{HNO}_{3}-\mathrm{H}_{2} \mathrm{O}_{2}$ mixture on hot plates including blanks and standards (see N'Guessan et al., 2009). Sequential extraction procedures were conducted on a subset of 5 flood samples taken during the same event (i.e. late may 2007, see also Fig. 2). The procedure (see for details Leleyter and Probst, 1999) aimed to separate seven geochemical labile phases in river sediment (water soluble, exchangeable, acid-soluble, bound to Mn oxides, amorphous and crystalline Fe oxides and oxidizable fraction). Total digestions and sequential extraction procedures were conducted in a clean room. Analytical accuracy for total trace elements was determined by the use of certified standards (i.e. MESS-2, GSMS-2 and GSMS-3) and provided suitable recoveries (errors $<10 \%$ for $\mathrm{Cd}$ and $\mathrm{Tb}$ and $<5 \%$ for the other elements).

Water discharge at the outlet of the catchment was inferred from water surface elevation above a gauging station (V-shaped weir). The YSI multi-parameter sensor was calibrated for this pur- pose, measuring water height variability with 10-min running intervals, from early October 2006 to late September 2007.

\subsection{Hydro-meteorological context over the study period}

On the basis of high-resolution monitoring, the hydrograph of the Montoussé stream was reconstructed (Fig. 2) together with rainfall data and suspended particulate matter content for the 72 samples. Results show low flow usually observed in the stream, punctuated by storm discharge peaks, during which the concentration of solids increased. The response of the river to precipitation events was not systematic, especially over the dry season, which likely reflects low aquifer recharge and/or evapotranspiration loss, while it was rather immediate when occurring during the wet period. This discharge pattern is rather representative of that usually observed for this stream (Perrin et al., 2008; Ferrant et al., 2012).

Three important flash-floods were identified during the study period, where maximum discharges exceeded $150 \mathrm{~L} \mathrm{~s}^{-1}$ (i.e. about 22 -fold the mean streamflow calculated for the study period). These events occurred within a short span of time, from early May to early June 2007, which coincided with the heaviest precipitation recorded over the study period. However, only the flood of late May 2007 is of paramount importance in terms of water discharge (peak recorded at $587 \mathrm{~L} \mathrm{~s}^{-1}$ ), solid discharge (peak at $7.9 \mathrm{~kg} \mathrm{~s}^{-1}$, extrapolated from water discharge data) and duration ( $16 \mathrm{~h}$ during which discharge exceeded $150 \mathrm{~L} \mathrm{~s}^{-1}$ ).

The main hydrological stats of the Montoussé (i.e. mean, minimum and maximum water discharge and SPM content) are summarized in Table 2. Data are coherent with our understanding of the local climatology, characterized by semi-arid conditions in summer due to high evapotranspiration (see also Section 2.1 and Table 1). One can note the very low mean streamflow (i.e. $6.9 \mathrm{~L} \mathrm{~s}^{-1}$ ), which was 85-fold lower than the highest discharge registered during the flood episode of late May 07. During summer, the water discharge reached its minimum, close to zero (i.e. $\left.0.1 \mathrm{~L} \mathrm{~s}^{-1}\right)$.

\subsection{Flux calculation}

Dissolved and particulate fluxes of metals leaving the Montoussé catchment were estimated on the basis of water discharge and SPM data, as well as metal content analyses. The collection of samples, increased during floods, was assumed sufficient for the calculation of event-related, monthly and annual fluxes. However, water discharge and SPM concentrations vary much more than metal contents in fluvial systems (Audry et al., 2004). Minimizing the degree of uncertainty attached to these two parameters is therefore a prerequisite for a reliable estimate of output metal fluxes.

\subsubsection{Water fluxes}

The requirement for accurate flux assessment was implicitly met for water discharge owing to high-frequency monitoring and the volume $Q^{\prime}$ of water supplied over a given period of time was calculated as the sum of the following product:

$Q^{\prime}=\sum_{i=1}^{n} \bar{Q}_{i} \cdot t_{i}$

where $\bar{Q}_{i}$ is the mean water discharge between two consecutives measurements and $t_{i}$ the related time interval. Then, dissolved fluxes of a given metal $M\left(F_{\text {dis }}(M)\right)$ were estimated using the weighted concentrations:

$F_{\text {dis }}(M)=\left(\sum_{i=1}^{n} Q_{i} \cdot C_{\text {dis }}(M)_{i} / \sum_{i=1}^{n} Q_{i}\right) \cdot Q^{\prime}$ 


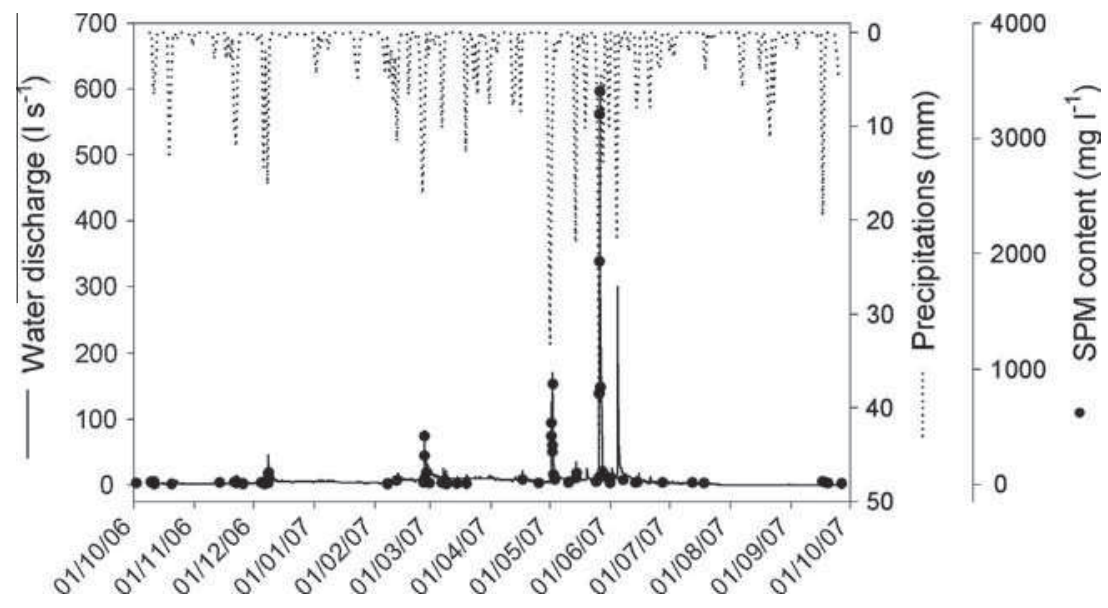

Fig. 2. Hydrograph (solid line) of the Montoussé stream between October 2006 and September 2007. Rainfall data (dashed line), as well as suspended sediment concentrations (points) measured for 72 samples are also presented.

Table 2

Hydrological features of the Montoussé stream during the study period.

\begin{tabular}{lll}
\hline & Water discharge $\left(\mathrm{L} \mathrm{s}^{-1}\right)$ & SPM conc. $\left(\mathrm{mg} \mathrm{L}^{-1}\right)^{\mathrm{a}}$ \\
\hline All data & & \\
Mean & 6.9 & 23.0 \\
Min & 0.1 & 7 \\
Max & 587 & 13,524 \\
Excluding discharges $>150 \mathrm{~L} \mathrm{~s}^{-1}$ & \\
Mean & 6.3 & 15.6 \\
Min & 0.1 & 7 \\
Max & 148 & 684 \\
\hline
\end{tabular}

${ }^{a}$ Extrapolated from water discharge data (see Section 2.4.2). SPM: Suspended particulate matter.

where $C_{d i s}(M)_{i}$ is the dissolved metal content in sample $i, Q_{i}$ the corresponding instantaneous river water flow and $Q^{\prime}$ the above-described volume of water discharged during the period investigated.

\subsubsection{Suspended particulate matter fluxes}

The assessment of SPM fluxes is complicated by large time intervals between consecutive water samples. We followed therefore the idea that SPM content could be predicted from the large water discharge dataset, in order to improve accuracy for SPM yields over the period of concern. For this purpose, an empirical,

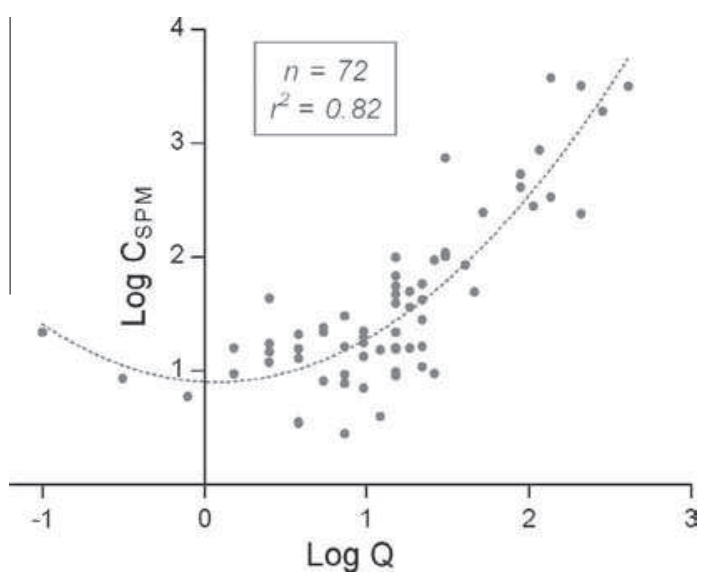

Fig. 3. Water discharge vs. SPM content ( $\log / \log )$ relationship established with the data of 72 samples taken at the outlet of the Montoussé stream. 2-order law (3) was constructed from the water discharge and SPM content data of the collected 72 samples. The resulting fit appears reasonably good (Fig. 3).

$$
\begin{aligned}
\log C_{\text {SPM }} & =0.4509 \log Q^{2}-0.0619 \log Q+0.847 \quad(n \\
& \left.=72, r^{2}=0.82\right)
\end{aligned}
$$

$C_{\mathrm{SPM}}$ is the SPM concentration in the water sample and $Q$ is the instantaneous water discharge when sample was taken. Estimated SPM loads were then computed to sum SPM yields $\left(Q_{S P M}^{\prime}\right)$ over the period concerned as follows:

$Q_{\mathrm{SPM}}^{\prime}=\sum_{i=1}^{n} \overline{\mathrm{SPM}}_{i} \cdot \bar{Q}_{i} \cdot t_{i}$

where $\overline{S P M}_{i}$ and $\bar{Q}_{i}$ are respectively the mean SPM concentration and the mean water discharge between two consecutives measurements, and $t_{i}$ the related time interval. Then, particulate fluxes of a given metal $M\left(F_{\text {part }}(M)\right)$ were estimated using the weighted concentrations:

$F_{\text {part }}(M)=\left(\sum_{i=1}^{n} Q_{\mathrm{SPMi}} \cdot C_{\text {part }}(M)_{i} / \sum_{i=1}^{n} Q_{\mathrm{SPMi}}\right) \cdot Q_{\mathrm{SPM}}^{\prime}$

where $C_{\text {part }}(M)_{i}$ is the particulate metal content in sample $i, Q_{\text {SPMi }}$ the corresponding instantaneous solid discharge and $Q_{S P M}^{\prime}$ the SPM quantity discharged during the period investigated. The latter parameter was estimated by water discharge data via Eq. (3).

\subsubsection{Uncertainty related to particulate flux assessment}

When computing sediment loads on the basis of log-transformed models, it is recommended to correct for biases that are amplified on conversion back to real space (Duan, 1983; Helsen and Hirsch, 2002). The application of the non-parametric bias correction factor proposed by the latter authors on our modelcalibration dataset was tested and results showed that estimates of suspended sediment loads for low and medium water discharges were generally improved compared to non-corrected estimates, but overestimation occurred dramatically for high water flow. Owing to the flood-dominated regime of the Montoussé stream, we therefore decided not to correct our data for retransformation bias.

Calculation errors applied to particulate flux estimates were based on the mean relative deviation $d$ of our field data to the model (1), weighted by the sediment discharges, as follows: 


$$
\begin{aligned}
d & =\sqrt{\sum_{i=1}^{n} Q_{\text {SPMi }} \cdot C V_{i}^{2} / \sum_{i=1}^{n} Q_{\text {SPMi }}} \text { with } C V_{i} \\
& =\left(Q_{\text {SPMi }}-Q_{\text {SPMi }}^{m}\right) / Q_{\text {SPMi }}
\end{aligned}
$$

where $C V_{i}$ is the coefficient of variation for sample $i$ and $Q_{\text {SPMi }}^{m}$ is the instantaneous SPM flux predicted by model (1). Errors inherent to each calculation of a solid flux $F_{\mathrm{SPM}}$ are balanced between overand underestimation in the range given by:

$F_{\mathrm{SPM}}=Q_{\mathrm{SPM}}^{\prime} \pm Q_{\mathrm{SPM}}^{\prime} \cdot 0.5 \cdot d$

\section{Results and discussion}

\subsection{Metal signatures of water and suspended particles}

\subsubsection{Total metal concentrations and inter-relationships}

Ranges of metal contents and their means observed over the study period in both the liquid and solid phases are presented in Table 3. When compared to other systems, it appears that the Montoussé stream exhibited typical levels of human-impacted rivers. $\mathrm{As}, \mathrm{Cr}, \mathrm{Cu}, \mathrm{Ni}$ and $\mathrm{Zn}$ contents are rather similar to those measured by Audry et al. (2004) in the downstream part of the nearby Garonne River, and by Aubert et al. (in preparation) in its upstream part. Only $\mathrm{Cd}$ and $\mathrm{Pb}$ show much lower concentrations compared to the latter river. The metal signature of the Montoussé stream is also very close to that registered in other small agricultural catchments (e.g. Xue et al., 2000; Miller et al., 2003).

In order to find out specific affinities between metals and hence to improve our understanding on their dynamics and transport within the Montoussé stream, inter-elemental correlation matrixes are presented in Table 4A and B for particulate and dissolved metals, respectively. In all cases, data are homogenously distributed along trend line (not shown), which tends to authenticate the nature of the relationships. Particulate metals typically depict a strong positive correlation with $\mathrm{Al}$, Fe and Sc (i.e. typical alumino-silicate proxies), although it is much less marked for Cd and Mn. These significant correlations suggest that particulate trace metals are mainly transported by fine-grained and clay-sized particles, either as inert constituents of their crystal lattice or adsorbed on them, probably mediated by $\mathrm{Al}$ and Fe oxyhydroxydes. However, the role of other coating formations like carbonates, organic phase and sulphides cannot be ruled out (see Section 3.3.4). Neither the water discharge nor the SPM content correlate to the concentrations $\left(\mu \mathrm{g} \mathrm{g}^{-1}\right)$ of particulate metals. Regarding dissolved metals, it is much more difficult to identify a common pattern. However, there are significant positive correlations between water discharge and dissolved $\mathrm{Cr}$, As, $\mathrm{Ni}$ and $\mathrm{Cu}$ (and to a lesser extent dissolved $\mathrm{Cd}$ and $\mathrm{Pb}$ ), which suggests their mobilization with increasing stream discharge (see below; the opposite trend being observed for Fe).

\subsubsection{Metal dynamics during high water discharge}

During the flood event of May 2007 (i.e. the most extreme hydrological event over the study period), all trace metals investigated here displayed lower partition coefficients (Kds) in comparison with their respective pre-flood signatures (not shown). This indicates that a greater proportion of dissolved metals with respect to their particulate forms occurred at that occasion. Indeed, during the flood, mean particulate contents of metals in SPM decreased (by a factor of 2.2-2.7, depending on the element, not shown), while in the meantime their mean dissolved contents increased (by a factor of 1.03-3.4, depending on the element, not shown).

A reduction of particulate metal contents is often observed when streamflow (and hence SPM content) increases dramatically (a phenomenon called p.c.e. or particle concentration effect). Some researchers reason that this is due to the dilution effect by coarser (i.e. less metal-reactive) particles resuspended from the bottom/ bank sediments (e.g. Benoit et al., 1994), as well as adsorption onto colloidal materials (Benoit and Rozan, 1999; Guégen and Dominik, 2003). Nevertheless, it appears evident that the effects of erosive and particle mixing processes on $\mathrm{Kd}$ values are combined with that of massive desorption mechanisms that enriches the liquid phase (perhaps mediated via colloids) in trace metals. This process can be illustrated by plotting the relationship between dissolved metal concentrations and stream discharge during the event (Fig. 4). Following the chronological order of sampling, $\mathrm{Cr}, \mathrm{Cu}$ and As exhibit clearly higher concentrations during the rising limb of the hydrograph than at the same discharge on the falling limb, forming typical clockwise hysteresis loops. For the other metals, the trend, albeit discernible, is less pronounced $(\mathrm{Ni})$ or well-established $(\mathrm{Pb}$, $\mathrm{Zn}$ ). These patterns reflect generally a major contribution from surface runoff as already shown by Probst and Bazerbachi (1986) due to the rapid flushing of soluble materials from the upper soil horizons at the beginning of the rain event, which likely occurred in the study area at that moment since no major runoff could have previously leached the land surface (see Fig. 2). The same pattern was already observed in the same area for hydrophobic molecules of pesticides (Taghavi et al., 2010, 2011).

\subsection{Metal enrichment factors in stream and pollution sources}

To determine the degree to which agricultural activities affect the metal concentrations in SPM of the Montoussé, enrichment factors (EFs) - as defined by Sutherland (2000) - were calculated. In order to provide EFs as accurately as possible, we used the mean signature of Gascogne bedrocks (molasse) considered as a suitable proxy for the natural background in the region (N'Guessan et al., 2009), and Sc as a normalizing element (chosen here for its highly significant relationship with $\mathrm{Al}$, see Table $4 \mathrm{~A}$ ). Albeit there is no general consensus concerning the natural variability threshold, it is generally suggested that $\mathrm{EF}>2$ is indicative of a probable anthro-

Table 3

Range of metal contents and their means observed over the study period in both solution and solid phases at the outlet of the Montoussé stream. Partition coefficients (Kd) are

\begin{tabular}{|c|c|c|c|c|c|c|c|c|c|c|c|}
\hline & $\mathrm{Al}$ & $\mathrm{Fe}$ & $\mathrm{Mn}$ & Sc & $\mathrm{Cr}$ & $\mathrm{Ni}$ & $\mathrm{Cu}$ & $\mathrm{Zn}$ & $\mathrm{Pb}$ & As & $\mathrm{Cd}$ \\
\hline Dissolved phase & $\mu \mathrm{g} \mathrm{L}^{-1}$ & $\mu \mathrm{g} \mathrm{L}^{-1}$ & & & $n g L^{-1}$ & $n g \mathrm{~L}^{-1}$ & $n g \mathrm{~L}^{-1}$ & $\mathrm{ng} \mathrm{L}^{-1}$ & $n g L^{-1}$ & $n g \mathrm{~L}^{-1}$ & $n g \mathrm{~L}^{-1}$ \\
\hline Range of contents & $0.12-97$ & $302-950$ & 1 & 1 & $u-204$ & $890-2446$ & 497-9050 & $1070-32,790$ & $11-138$ & $547-2218$ & $u-68$ \\
\hline Mean contents & 3.1 & 565 & 1 & 1 & 51 & 1643 & 1232 & 3033 & 32 & 1160 & 4.3 \\
\hline Particulate phase & $\%$ & $\%$ & $\mu \mathrm{g} \mathrm{g}^{-1}$ & $\mu \mathrm{g} \mathrm{g}^{-1}$ & $\mu \mathrm{g} \mathrm{g}^{-1}$ & $\mu \mathrm{g} \mathrm{g}^{-1}$ & $\mu \mathrm{g} \mathrm{g}^{-1}$ & $\mu \mathrm{g} \mathrm{g}^{-1}$ & $\mu \mathrm{g} \mathrm{g}^{-1}$ & $\mu \mathrm{g} \mathrm{g}^{-1}$ & $\mu \mathrm{g} \mathrm{g}^{-1}$ \\
\hline Range of contents & $1.3-21.7$ & $0.7-12.7$ & $492-5203$ & $2.7-38$ & $15-298$ & $9.7-186$ & $6.4-105$ & $47-476$ & $4.1-66$ & $5.7-70$ & $0.1-3$ \\
\hline Mean contents & 8.8 & 5 & 1916 & 15.8 & 115 & 70 & 45 & 223 & 30 & 30 & 1 \\
\hline $\begin{array}{l}\log \mathrm{Kd}\left(10^{3} \mathrm{Lg}^{-1}\right) \\
\text { Range of values }\end{array}$ & 1 & 1 & 1 & 1 & $5.6-6.9$ & $3.8-5.1$ & $4.0-5.1$ & $4.1-5.6$ & $5.4-6.5$ & $3.8-4.9$ & $4.1-5.6$ \\
\hline
\end{tabular}
also presented for a selection of trace metals.

$u$ : Undetected (i.e. concentration considered equal to $0 \mathrm{ng} \mathrm{L}^{-1}$ ). /: not presented.

a $n=53$ Except for $\mathrm{Cr}(n=51)$ and $\mathrm{Cd}(n=21)$ due to detection limits in the dissolved phase. 
Table 4

A: Pearson correlation matrix for particulate metal concentrations $\left(\mu \mathrm{g} \mathrm{g}^{-1}\right)$. Water discharge $(\mathrm{Q})$ and suspended particulate matter (SPM) concentration are also included. Values refer to Pearson coefficients $(\mathrm{R}), n=53$. Significant correlations at $p<0.05$ are in bold. B: Pearson correlation matrix for dissolved metal concentrations ( $\mu \mathrm{g} \mathrm{L}^{-1}$ ). Water discharge (Q) is also included. Values refer to Pearson coefficients (R), $n=72$. Significant correlations at $p<0.05$ are in bold.

\begin{tabular}{|c|c|c|c|c|c|c|c|c|c|c|c|c|c|c|}
\hline A & Q & SPM & $\mathrm{Al}$ & $\mathrm{Fe}$ & Mn & Sc & $\mathrm{Cr}$ & $\mathrm{Ni}$ & $\mathrm{Cu}$ & $\mathrm{Zn}$ & & $\mathrm{Pb}$ & As & $\mathrm{Cd}$ \\
\hline Q & 1 & & & & & & & & & & & & & \\
\hline SPM & 0.93 & 1 & & & & & & & & & & & & \\
\hline $\mathrm{Al}$ & -0.13 & -0.13 & 1 & & & & & & & & & & & \\
\hline $\mathrm{Fe}$ & -0.02 & -0.02 & 0.89 & 1 & & & & & & & & & & \\
\hline Mn & -0.32 & -0.25 & 0.58 & 0.57 & 1 & & & & & & & & & \\
\hline Sc & -0.11 & -0.11 & 0.99 & 0.91 & 0.60 & 1 & & & & & & & & \\
\hline $\mathrm{Cr}$ & 0.01 & 0.01 & 0.87 & 0.99 & 0.57 & 0.89 & 1 & & & & & & & \\
\hline $\mathrm{Ni}$ & 0.03 & 0.03 & 0.83 & 0.98 & 0.55 & 0.85 & 0.98 & 1 & & & & & & \\
\hline $\mathrm{Cu}$ & -0.01 & -0.01 & 0.74 & 0.88 & 0.58 & 0.76 & 0.88 & 0.88 & 1 & & & & & \\
\hline $\mathrm{Zn}$ & -0.12 & -0.09 & 0.87 & 0.92 & 0.71 & 0.88 & 0.91 & 0.89 & 0.83 & 1 & & & & \\
\hline $\mathrm{Pb}$ & 0.02 & 0.03 & 0.89 & 0.96 & 0.56 & 0.91 & 0.96 & 0.92 & 0.83 & 0.90 & & 1 & & \\
\hline As & -0.04 & -0.03 & 0.86 & 0.98 & 0.59 & 0.88 & 0.98 & 0.96 & 0.86 & 0.92 & & 0.93 & 1 & \\
\hline $\mathrm{Cd}$ & -0.20 & -0.13 & 0.50 & 0.56 & 0.71 & 0.54 & 0.54 & 0.55 & 0.53 & 0.73 & & 0.51 & 0.56 & 1 \\
\hline B & $\mathrm{Q}$ & $\mathrm{Al}$ & & $\mathrm{Fe}$ & $\mathrm{Cr}$ & $\mathrm{Ni}$ & & $\mathrm{Cu}$ & $\mathrm{Zn}$ & & $\mathrm{Pb}$ & & As & $\mathrm{Cd}$ \\
\hline Q & 1 & & & & & & & & & & & & & \\
\hline $\mathrm{Al}$ & -0.04 & 1 & & & & & & & & & & & & \\
\hline $\mathrm{Fe}$ & -0.31 & 0.11 & & 1 & & & & & & & & & & \\
\hline $\mathrm{Cr}$ & 0.88 & 0.00 & & -0.31 & 1 & & & & & & & & & \\
\hline $\mathrm{Ni}$ & 0.39 & 0.06 & & 0.44 & 0.42 & 1 & & & & & & & & \\
\hline $\mathrm{Cu}$ & 0.40 & 0.64 & & -0.17 & 0.55 & 0.31 & & 1 & & & & & & \\
\hline $\mathrm{Zn}$ & -0.12 & 0.02 & & 0.01 & -0.08 & -0.01 & & -0.02 & 1 & & & & & \\
\hline $\mathrm{Pb}$ & 0.20 & -0.04 & & -0.11 & 0.27 & 0.29 & & 0.13 & 0.20 & & 1 & & & \\
\hline As & 0.62 & 0.01 & & -0.05 & 0.70 & 0.57 & & 0.51 & -0.16 & & 0.13 & & 1 & \\
\hline $\mathrm{Cd}$ & 0.22 & -0.01 & & -0.05 & 0.30 & 0.37 & & 0.34 & -0.11 & & 0.26 & & 0.58 & 1 \\
\hline
\end{tabular}

pogenic influence (e.g. Hernandez et al., 2003). Results are presented in Fig. 5 for the most interesting elements, in the form of box plots. What is immediately apparent from these plots is that almost all the EFs are distributed around the limit of natural variability, with values stretching between natural and enhanced levels. Median EF values vary between $1.2(\mathrm{~Pb})$ to $4.2(\mathrm{Cd})$, indicating deficient to moderate contamination for most samples. Except for $\mathrm{Cu}$ and $\mathrm{Ni}$, these mean EFs are lower than those found in other agricultural sites, e.g. in top soils from the densely populated and industrialized Northern France region (Bourennane et al., 2010) and in river SPM from two small-scale watersheds within the Chesapeake Bay basin (Miller et al., 2003). The relatively low contamination observed in the Montoussé stream likely results from the combination of low population/industry density and sustainable farming practices based on reduced chemical fertilizer applications and on the presence of riparian strip-bands as buffering zones which slow down the transfer of metal bearing particles from the soils to the stream.

Upon closer examination, two groups of elements can be distinguished. It appears that $\mathrm{Cd}, \mathrm{Cu}, \mathrm{Ni}$ and $\mathrm{Zn}$ exhibit a median $\mathrm{EF}$ value exceeding the natural threshold with few values in the natural range. For the other elements $(\mathrm{Cr}$, As and $\mathrm{Pb})$, more than half of the EFs were below this limit and an anthropogenic influence is only suggested on some occasions (note that As is naturally enriched in the local molasse compared to average shale, N'Guessan et al., 2009). The occurrence of metal enrichment/contamination (expressed as the number of samples for which $\mathrm{EF}>2$ ) in the 53 river SPM samples follows the order of $\mathrm{Cd}(52)>\mathrm{Zn}=\mathrm{Ni}(48)>\mathrm{Cu}$ (33) $>\mathrm{Cr}=\mathrm{As}(7)>\mathrm{Pb}$ (3). From this contamination pattern, one can provide evidence on the pollution sources for the study area. On the one hand, $\mathrm{Cd}, \mathrm{Zn}, \mathrm{Ni}$ and to a lesser extent Cu exhibit an anthropogenic profile that is coherent with a diffuse contamination of soils. Metals can accumulate in agricultural soils under the form of impurities/constituents of fertilizers (e.g. Mordvet and Osborn, 1982; Nziguheba and Smolders, 2008). In a recent investigation, 4 types of fertilizers typically used by the Montoussé farmers were analysed for total trace metal concentrations (Bur, 2008). With respect to the mean composition of the local molasse (data not de- tailed here), three of them were characterized by high concentrations of $\mathrm{Cd}$ (4, 6 and $\left.14 \mu \mathrm{g} \mathrm{g}^{-1}\right), \mathrm{Zn} \mathrm{(17,} 122$ and $\left.217 \mu \mathrm{g} \mathrm{g}^{-1}\right)$ and $\mathrm{Cu}\left(6,9\right.$ and $22 \mu \mathrm{g} \mathrm{g}^{-1}$ ), hence contributing to the enrichment of these metals in soils (Note that $\mathrm{Pb}$ concentrations were always below $1.5 \mu \mathrm{g} \mathrm{g}^{-1}$ and As was not measured). On the other hand, the group of $\mathrm{Cr}$, As and $\mathrm{Pb}$ mostly originates from natural weathering and one can suggest that their episodic anthropogenic signature derives mainly from the atmospheric fallout, as already shown for river sediments from the upper part of the Gascogne area (N'Guessan et al., 2009).

\subsection{Metals exported from the Montoussé catchment}

\subsubsection{Fluxes of water and suspended particulate materials}

Instantaneous discharges were integrated and results indicated that the Montoussé stream yielded $214 \times 10^{3} \mathrm{~m}^{3}$ of water and $109.9 \mathrm{t}( \pm 23.7 \mathrm{t})$ of SPM, respectively (Table 1$)$, over the $1-\mathrm{yr}$ survey.

The period from February to June 2007 exhibits higher water fluxes and a higher mean streamflow $\left(11 \mathrm{~L} \mathrm{~s}^{-1}\right)$ compared to the entire study period, which is mainly explained by the local seasonal precipitation pattern (Fig. 2). The highest water flux is recorded in May 2007, a period during which a mean streamflow of $19 \mathrm{~L} \mathrm{~s}^{-1}$ is recorded $\left(13.5 \mathrm{~L} \mathrm{~s}^{-1}\right.$ when excluding water discharge conditions $>150 \mathrm{~L} \mathrm{~s}^{-1}$ ). The significance of the flood of May in the water delivery is rather important: $30 \%$ of the monthly water yield (and $8 \%$ of the annual water yield) was exported in $16 \mathrm{~h}$.

Regarding mean SPM fluxes, the monthly delivery is sporadic and almost entirely focused on May 2007. Indeed, $91 \%$ of the annual yield occurred during this month. The contribution of the flood of late May 2007 for the sediment mass transfer is shown to be considerable; it accounts for $94 \%$ and $86 \%$ of the monthly and annual SPM deliveries, respectively. The implications of this, in terms of metal export, are discussed below.

\subsubsection{Fluxes of dissolved and particulate total metals}

Dissolved and particulate total metal fluxes were calculated following the method detailed in Section 2.4. When converting data 

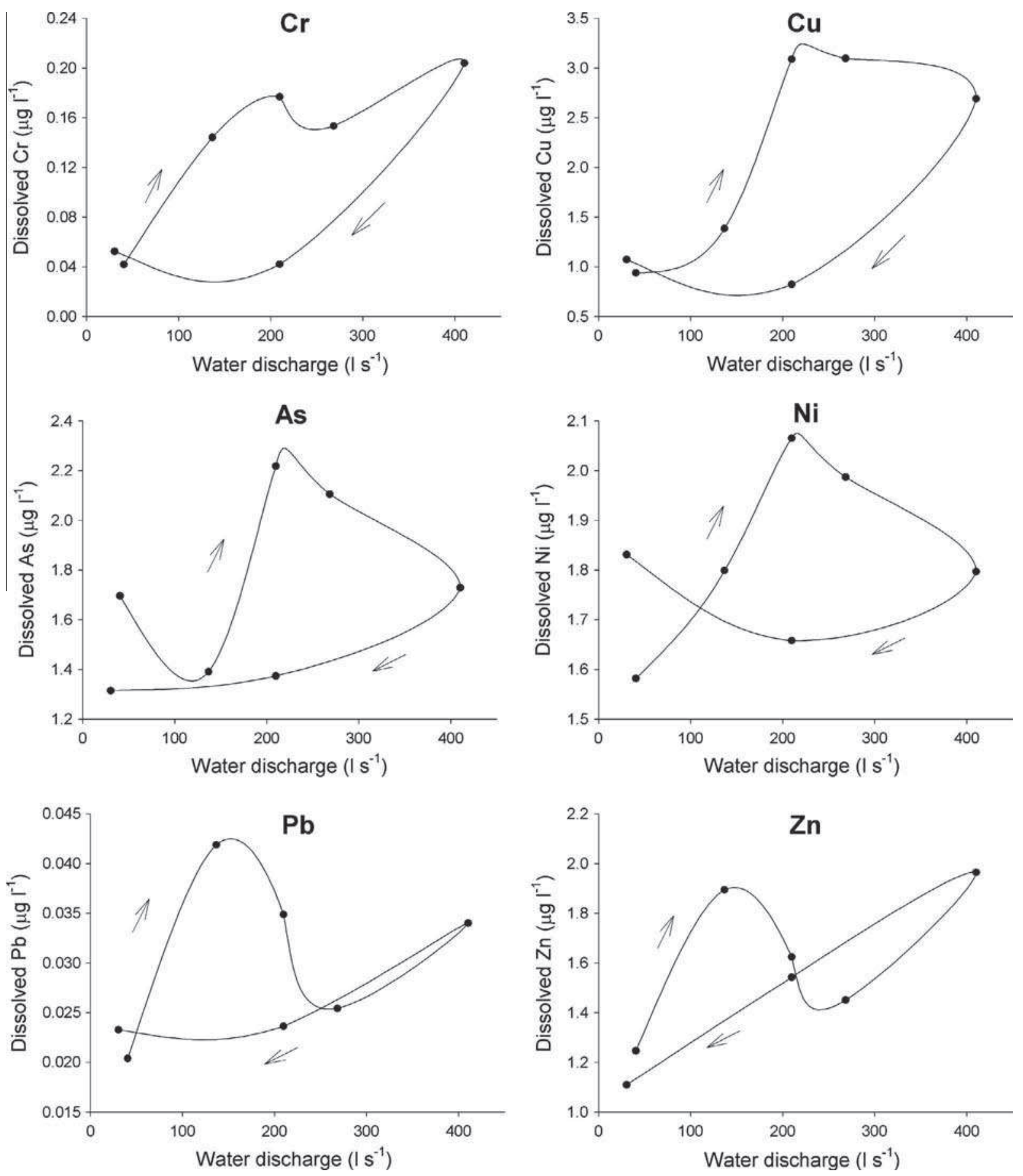

Fig. 4. Temporal evolution of dissolved contents of $\mathrm{Cr}, \mathrm{Cu}, \mathrm{As}, \mathrm{Ni}, \mathrm{Pb}$ and $\mathrm{Zn}$ during the flood event of late May 2007 ( $16 \mathrm{~h}$ during which stream flow exceeds $150 \mathrm{~L} \mathrm{~s}{ }^{-1}$ ).

into annual estimates, particulate yields largely exceed dissolved yields, with differences ranging from 1 to 3 orders of magnitude (Table 5). The main reason is that, in this carbonate catchment, pH conditions (mean $\mathrm{pH}=8.1$, Perrin et al., 2008) favor the association of metals with particles. Under such circumstances, and because of the highly contrasted discharge regime (a very low baseline streamflow punctuated by sporadic flash-floods) dissolved fluxes of metals are extremely low and their particulate fluxes much higher in proportion. Such conditions are poorly reported in the literature.

Unsurprisingly, the distribution over time of both dissolved and particulate metal yields is intimately linked to that of water and SPM, respectively (not shown). The contribution of the flood event of late May 2007 is therefore much more important regarding annual particulate fluxes (72-82\%, depending on the element) than for annual dissolved fluxes (0-20\%, depending on the element) of the metals investigated here (Table 5). It might therefore be argued that SPM fluxes (and by extension flood events) represent the main controlling factor of metal transfer in the study area.

\subsubsection{Origin of river particles}

Rare earth elements (REE, i.e. from La to Lu) are characterized by strong partitioning in the particulate phase and depict coherent behavior during weathering and erosion processes, as well as during river transport (Xu et al., 2009). In addition, they can easily characterize and discriminate between materials (Song and Choi, 


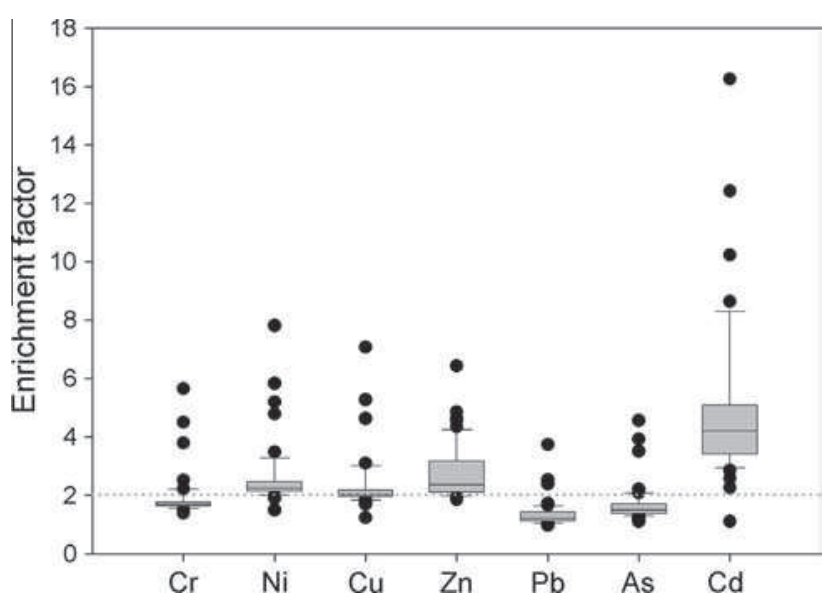

Fig. 5. Box plot representation of enrichment factors for some trace metals measured over the study period in suspended particulate matter of the Montoussé stream.

2009), making them useful for determining the provenance of sediments in hydro-systems.

Selected particulate samples were considered to question the validity of REE pattern continuity before, during and after the flood event of late May 2007. To facilitate data comparison and to evaluate the variation in REE abundance, our data have been normalized to Post Archean Australian Shale (PAAS, from McLennan, 1989). Results shown that all spectra depict the same shape (Fig. 6), reflecting implicitly a common lithogenic origin, irrespectively of water discharge. Nonetheless, REE patterns of stream particles strongly resemble those of local soil horizons analysed by Bur (2008) who found slight enrichments of medium REE and depletion of heavy REE compared to PAAS. The role of these local soils as the main source of materials for the Montousse stream is confirmed by the flat REE spectra (Fig. 6), obtained when using one of these representative samples (local deep soil horizon) as a normalizer material, rather than to use PAAS. Such findings also attest that (i) no drastic modification occurred in REE geochemistry during soil erosion and (ii) fertilizer amendments, which depict different REE spectra compared to local soils (Bur, 2008), did not influence significantly the REE abundance in soils, as suggested by the latter author.

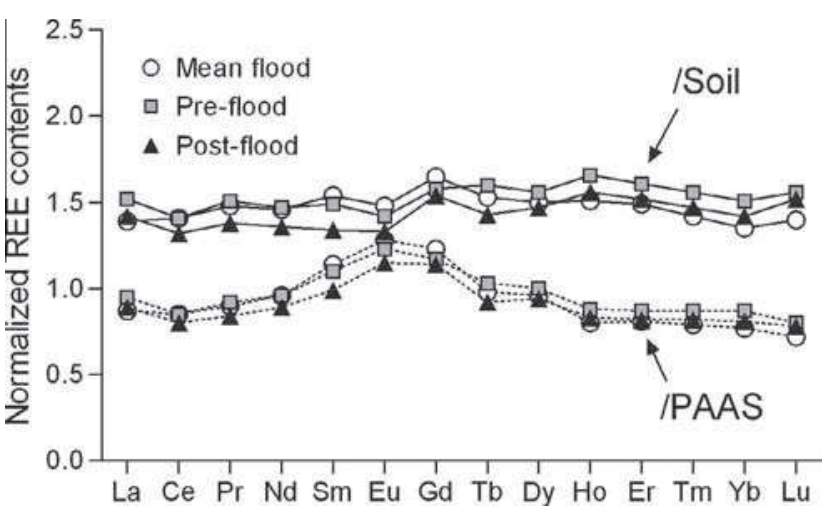

Fig. 6. REE distribution patterns of selected samples normalized distinctively to PAAS and local deep soil horizon, as indicated. Open circles correspond to mean flood values ( $n=5$ samples taken the 26th of May), black squares correspond to the pre-flood signature (sample taken the 10th of May 2007) and up triangles refer to the post-flood signature (sample taken the 31th of May 2007).

\subsubsection{Anthropogenic particulate metal fluxes and environmental implications}

Given the significance of the particulate phase in the transfer of metals through the Montoussé riverine system (see above), the major part of their anthropogenic forms is likely exported in association with suspended solids. From both environmental and ecological viewpoints, it is therefore crucial to evaluate the anthropogenic fraction of particulate metals impacting the downstream-connected hydrosystems. A distinction between natural (at maximum level) and anthropogenic particulate fluxes can be readily done, deriving from the calculation of enrichment factors (see Hissler and Probst, 2006; N'Guessan et al., 2009), as defined by Roussiez et al. (2012). For a given metal M and period, the respective contributions were determined as follows:

$$
\begin{aligned}
& F_{\text {part_nat_max }}(M)=2 \cdot F_{\text {part }}(S c) \cdot\left(\frac{[M]}{[S C]}\right)_{\text {Background }} \\
& F_{\text {part_anth }}(M)=F_{\text {part_total }}(M)-F_{\text {part_nat_max }}(M)
\end{aligned}
$$

where $F_{\text {part_nat_max }}(M)$ is the natural particulate flux of a given metal $M$, at its maximum level (i.e. dictated by the natural variability threshold), while $F_{\text {part_anth }}(M)$ and $F_{\text {part_total }}(M)$ are its anthropo-

Table 5

Annual and event-related fluxes of dissolved and particulate metals. Uncertainties for annual and flood-related particulate fluxes were calculated following the method detailed in

\begin{tabular}{|c|c|c|c|c|c|c|c|c|c|c|}
\hline & $\mathrm{Al}$ & $\mathrm{Fe}$ & Mn & $\mathrm{Cr}$ & $\mathrm{Ni}$ & $\mathrm{Cu}$ & $\mathrm{Zn}$ & $\mathrm{Pb}$ & As & $\mathrm{Cd}$ \\
\hline \multicolumn{11}{|l|}{ Dissolved phase } \\
\hline Annual fluxes $\left(\mathrm{g} \mathrm{yr}^{-1}\right)$ & 641 & 117453 & 1 & 14 & 368 & 302 & 660 & 7.7 & 263 & 0.9 \\
\hline $\begin{array}{l}\text { Specific annual fluxes } \\
\qquad\left(\mathrm{g} \mathrm{km}^{-2} \mathrm{yr}^{-1}\right)\end{array}$ & 195 & 35,809 & i & 4.3 & 112 & 92 & 201 & 2.3 & 80 & 0.27 \\
\hline May 07 flood fluxes (g over $16 \mathrm{~h}$ ) & 38 & 7761 & 1 & 2.8 & 33 & 45 & 31 & 0.75 & 31 & 1 \\
\hline May 07 flood/annual (\% fluxes) & 6 & 7 & i & 20 & 9 & 15 & 12 & 10 & 12 & i \\
\hline \multicolumn{11}{|l|}{ Particulate phase } \\
\hline Annual fluxes $\left(\mathrm{kg} \mathrm{yr}^{-1}\right)$ & $\begin{array}{l}7924 \\
( \pm 1743)\end{array}$ & $\begin{array}{l}5551 \\
( \pm 1221)\end{array}$ & $131( \pm 29)$ & $13.5( \pm 3)$ & $\begin{array}{l}8.5 \\
( \pm 1.9)\end{array}$ & $\begin{array}{l}5.1 \\
( \pm 1.1)\end{array}$ & $\begin{array}{l}23.1 \\
( \pm 5.1)\end{array}$ & $\begin{array}{l}3.6 \\
( \pm 0.8)\end{array}$ & $\begin{array}{l}3.4 \\
( \pm 0.7)\end{array}$ & $0.09( \pm 0.02)$ \\
\hline $\begin{array}{l}\text { Specific annual fluxes } \\
\qquad\left(\mathrm{kg} \mathrm{km}^{-2} \mathrm{yr}^{1}\right)\end{array}$ & 2416 & 1692 & 40 & 4.1 & 2.6 & 1.6 & 7 & 1.1 & 1 & 0.03 \\
\hline May 07 flood fluxes (kg over $16 \mathrm{~h}$ ) & $\begin{array}{l}5856 \\
( \pm 1259)\end{array}$ & $4448( \pm 956)$ & $\begin{array}{l}94.5 \\
( \pm 20)\end{array}$ & $\begin{array}{l}11.1 \\
( \pm 2.4)\end{array}$ & $7( \pm 1.5)$ & $\begin{array}{l}4.2 \\
( \pm 0.9)\end{array}$ & $18.5( \pm 4)$ & $\begin{array}{l}2.9 \\
( \pm 0.6)\end{array}$ & $\begin{array}{l}2.7 \\
( \pm 0.6)\end{array}$ & $\begin{array}{l}0.07 \\
( \pm 0.015)\end{array}$ \\
\hline May 07 flood/annual (\% fluxes) & 74 & 80 & 72 & 82 & 82 & 82 & 80 & 81 & 81 & 78 \\
\hline \multicolumn{11}{|l|}{ Particulate/dissolved flux ratio } \\
\hline This study & 12,359 & 47 & 1 & 958 & 23 & 17 & 35 & 469 & 13 & 104 \\
\hline Lot river (France) ${ }^{\mathrm{a}}$ & 1 & 1 & i & 1 & 1 & 9.9 & 16 & 69 & 1 & 25 \\
\hline Garonne river (France) ${ }^{\mathrm{a}}$ & i & i & l & 1 & 1 & 3.8 & 2.4 & 33 & 1 & 16 \\
\hline Chesterville branch (USA) ${ }^{\mathrm{b}}$ & 298 & 24 & i & 2.1 & 1.2 & 1.3 & 3.6 & 39 & 1.3 & 1.6 \\
\hline
\end{tabular}
Section 2.4.3.

a Values for year 2000 (calculated from Audry et al., 2004).

b Calculated from Miller et al. (2003). 
Table 6

Monthly estimates of anthropogenic particulate metals in $\mathrm{g}$ and \% of total metals (natural plus anthropogenic) exported from the Montoussé catchment in association with river suspended particulate matter.

\begin{tabular}{|c|c|c|c|c|c|c|c|c|c|c|c|c|c|c|}
\hline \multirow[b]{2}{*}{ Period } & \multicolumn{2}{|l|}{$\mathrm{Cr}$} & \multicolumn{2}{|l|}{$\mathrm{Ni}$} & \multicolumn{2}{|l|}{$\mathrm{Cu}$} & \multicolumn{2}{|l|}{$\mathrm{Zn}$} & \multicolumn{2}{|c|}{$\mathrm{Pb}$} & \multicolumn{2}{|l|}{ As } & \multicolumn{2}{|l|}{$\mathrm{Cd}$} \\
\hline & g & $\%$ & g & $\%$ & $\mathrm{~g}$ & $\%$ & g & $\%$ & $\mathrm{~g}$ & $\%$ & g & $\%$ & g & $\%$ \\
\hline October 06 & 1 & 1 & 1 & I & 1 & 1 & 1 & 1 & 1 & 1 & 1 & 1 & 0.01 & 23 \\
\hline November & 1 & 1 & 0.4 & 6 & 1 & 1 & 0.1 & 1 & 1 & 1 & 1 & 1 & 0.04 & 46 \\
\hline December & 9.5 & 26 & 9.5 & 43 & 5.1 & 38 & 20.3 & 35 & 1 & 1 & 1.6 & 16 & 0.15 & 62 \\
\hline January & 1 & 1 & 0.9 & 7 & 0.4 & 5 & 2.2 & 6 & i & i & 1 & 1 & 0.04 & 34 \\
\hline February & 1 & 1 & 20.1 & 26 & 5.5 & 12 & 39.2 & 18 & I & 1 & I & 1 & 0.41 & 49 \\
\hline March & 1 & 1 & 2.2 & 12 & 1.8 & 14 & 30.7 & 38 & 1 & 1 & 1 & I & 0.18 & 60 \\
\hline April & i & 1 & 2.1 & 22 & 1 & 18 & 17.7 & 45 & 1 & 1 & 0.2 & 3 & 0.09 & 63 \\
\hline May & $2461( \pm 406)$ & 21 & $3105( \pm 368)$ & 42 & $1538( \pm 276)$ & 35 & $6683( \pm 621)$ & 34 & 1 & 1 & $106( \pm 27)$ & 4 & $42( \pm 5)$ & 57 \\
\hline June & 1 & 1 & 48.6 & 5 & 1 & 1 & 238.4 & 8 & I & 1 & 1 & 1 & 6.47 & 48 \\
\hline July & I & i & 0.2 & 8 & I & I & 0.3 & 4 & I & 1 & I & I & 0.02 & 50 \\
\hline August & 1 & l & 1 & 6 & 1 & 4 & 0.1 & 30 & i & i & 1 & 1 & 0.002 & 79 \\
\hline September 07 & 1 & l & 0.1 & 12 & 0.1 & 21 & 0.8 & 34 & l & l & 1 & l & 0.01 & 77 \\
\hline May 07 flood (\% of total supply) & 94 & & 92 & & 94 & & 89 & & i & & 97 & & 79 & \\
\hline
\end{tabular}

|: Value is equal to zero.
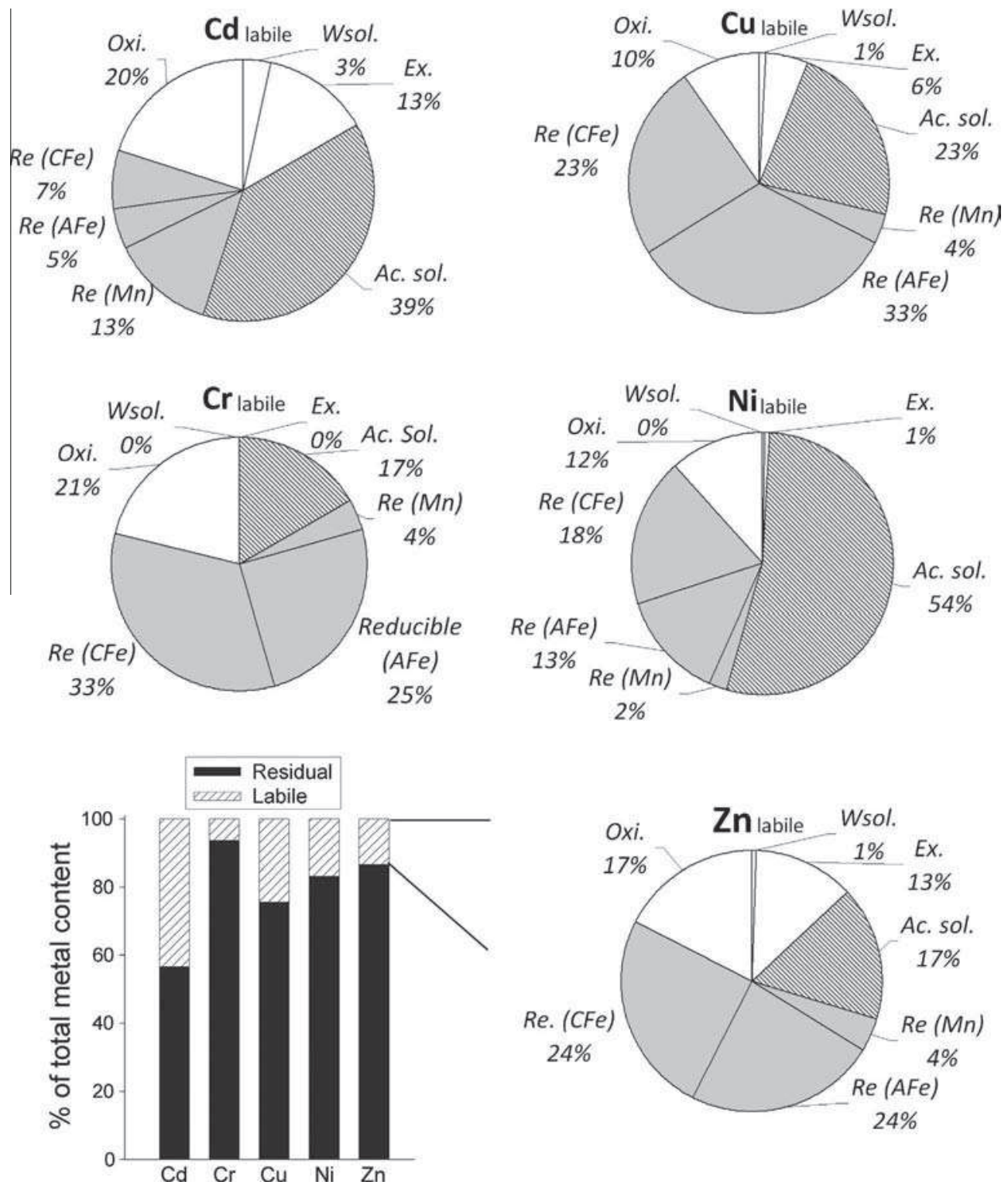

Fig. 7. Partitioning of labile particulate metals between the seven non-residual phases obtained following the sequential extraction procedure of Leleyter and Probst (1999) (see Section 2.2). Values in circle graphs correspond to the respective contributions (\%) of each non-residual phase to the total of labile metals in SPM. Stacked bars present the respective contributions (\%) of residual and labile forms of metals to the total (labile plus residual) concentrations in SPM. Wsol.: water soluble phase, Ex.: exchangeable phase, Ac. Sol.: acide soluble phase, Oxi.: oxidizable phase, Re (CFe): reducible phase of crystalline Fe oxides, Re (AFe): reducible phase of amorphous Fe oxides, Re (Mn): reducible phase of $\mathrm{Mn}$ oxides. 
genic and total particulate fluxes, respectively. $F_{\text {part }}(S c)$ is the particulate flux of Sc over the period of concern, as determined by Eq. (5). Because natural fluxes of metals were taken at their maximum level, negative $F_{\text {part_anth }}(M)$ values could be obtained and, in this case, were considered equal to zero. $[M]$ and $[S c]$ correspond respectively to the particulate concentrations of the metal $\mathrm{M}$ and Sc in the natural reference.

Monthly anthropogenic fluxes of metals associated with river SPM are detailed in Table 6. Quantitatively, and as expected from Section 3.3.2, the latter are concentrated in May 2007, and notably during the flood event, which accounts for $79-97 \%$ of the annual anthropogenic fluxes, depending on the element. Qualitatively, the monthly trace metal deliveries are composed of variable anthropogenic fractions (Table 6), probably related to amendment use and occurrence of land runoff. Over the 1-yr survey, the anthropogenic contribution decreased according to the following order: $\mathrm{Cd}(56 \%$ of $0.09 \mathrm{~kg})>\mathrm{Ni} \quad(37 \%$ of $8.5 \mathrm{~kg})>\mathrm{Zn}=\mathrm{Cu} \quad(30 \%$ of $23.1 \mathrm{~kg})>\mathrm{Cr}(18 \%$ of $13.5 \mathrm{~kg})>$ As $(3.2 \%$ of $3.4 \mathrm{~kg})>\mathrm{Pb}(0 \%$ of $3.6 \mathrm{~kg}$ ). This classification reflects in fine the potential threat the Montoussé stream posed for aquatic ecosystems receiving the contaminated particles over the study period and implications for environmental/ecological quality are discussed in the following.

Depending on the physico-chemical conditions encountered during their transport (e.g. pH, redox, ionic strength...), metals incorporated into labile phases can be mobilized to different degrees, thus becoming more bioavailable and possibly toxic for living organisms, as shown for soil derived particles (Bur et al., 2012). Moreover, these labile fractions are important bearing phases for anthropogenic metals (e.g. Argese et al., 1997). For these reasons, it is instructive to look at the partition of the enriched elements in the river SPM collected during the flood event of May 2007. The acido-soluble and reducible fractions are the two main host phases of labile metals in the Montoussé particles (Fig. 7). Labile Ni and Cd depict the highest affinity for carbonates and hence should be the most mobile elements under conditions of decreasing pH. Additionally, labile $\mathrm{Zn}, \mathrm{Cr}$ and $\mathrm{Cu}$ could be released under anoxic conditions, owing to their association with $\mathrm{Mn}$ and Fe oxides. To a lesser extent, approximately $10-20 \%$ of these labile metals are potentially mobilizable under oxic conditions ( via sulphide dissolution and/or particulate organic matter decomposition), although subsequent readsorption processes are possible (Sternbeck et al., 1999).

It is worthy to note that labile fractions in the studied flood samples represent lower contributions to the total metal concentrations in comparison with bottom sediments from rivers of the Gascogne area (N'Guessan, 2008). Flushing of metals from soils during the event may, at least partly, explain this (see Section 3.1.2). Also the good practices of local farmers likely contributed to attenuate the loading of non-residual phases in soils, and consequently in river SPM. Finally, aging processes in soils could also have transformed labile metals into non-labile forms (Ma et al., 2006).

These results denote that the Montoussé catchment forms, together with similar hydro-systems in upstream zones, a reservoir of contaminated particles - eroded from soils (see Section 3.3.3.), partially and temporarily stored in stream sediments (N'Guessan et al., 2009) - that sporadically exports part of them into larger river basins. It appears fundamental, therefore, to track the fate of these metals in order to better evaluate their environmental/ecological impact.

\section{Conclusions}

The survey of metal concentrations in both particulate and dissolved phases of the Montoussé stream from early October 2006 to late September 2007 resulted in the following conclusions:
- Metal signatures of both waters and suspended particulate matters exhibited typical levels of hydro-systems impacted by agricultural activities.

- Metal contamination in the river suspended particulate materials, mainly deriving from the use of fertilizers in surface soil layers, was shown to be deficient to moderate, depending on the element. This is likely the benefit of good agricultural practices started 20 years ago by the local farmers.

- Metal partitioning between particulate and dissolved phases was altered during flood conditions: the particulate phase was diluted by coarser and less contaminated particles from river bottom and banks, whereas the liquid phase was rapidly enriched owing to desorption mechanisms. Soluble/reactive elements were washed-off from soils at the beginning of the rain episode but the effect of physical disturbance cannot be ruled out in this respect.

- The contribution of the flood event of May 2007 (by far the most extreme episode over the study period) to annual metal export from the Montoussé catchment was shown to be considerable for particulate forms (72-82\%, depending on the element) and moderate for dissolved elements $(0-20 \%)$.

- Rare earth element (REE) investigation on selected samples (taken before, during and after the flood of May 2007) revealed that river-transported particles derive mainly from the local soils, irrespectively of the water discharge.

- The hydrological functioning of the Montoussé stream poses dual threat on aquatic ecosystems, the consequences of which differ from both temporal and spatial scales: (i) desorption processes at the beginning of floods locally induce a rapid enrichment (up to 3.4-fold the pre-flood signatures on average over the event of May 2007) of waters in bioavailable forms of metals, and (ii) labile (partly anthropogenic) metals associated with particles (mainly via carbonates and Fe/Mn oxides) are principally transferred during floods into downstream-connected rivers, where they could be mobilized depending on new $\mathrm{pH}$ or redox conditions encountered there.

- Further studies are needed to improve our understanding of the transfer of metals from soils to stream during wet episodes. Even if dissolved organic carbon (DOC) is limited in such kind of soils, special attention should be given to metal lability in surficial soil layers and the role of DOC as well as inorganic colloids at high $\mathrm{pH}(>6)$ as a vector for dissolved metals (Gandois et al., 2010).

\section{Acknowledgements}

The authors would like to thank Gaël Durbe, Jérôme Fauconnet, Dr. Laure Gandois and Dr. Thomas Bur from EcoLab (Castanet-Tolosan, France) and Carole Boucayrand and Frédéric Candaudap from LMTG (Toulouse, France) for their help in the field, during sample preparation and for the analytical work. Special thanks also go to two anonymous reviewers for their fruitful comments.

\section{References}

Adriano, D.C., 2001. Trace Elements in The Terrestrial Environment, second ed. Springer-Verlag, New York, NY.

Argese, E., Ramieri, E., Bettiol, C., Pavoni, B., Chiozzoto, E., Sfriso, A., 1997. Pollutant exchange at the water/sediment interface in the Venice canals. Water Air Soil Pollut. 99, 255-263.

Aubert, D., Probst, J.L., Probst, A. (in preparation). Influence of Hydrological Conditions on Trace Metal Behaviour and Dissolved/Particulate Partitioning in the Upper Garonne and Ariège rivers (SW, France).

Audry, S., Schäfer, J., Blanc, G., Bossy, C., Lavaux, G., 2004. Anthropogenic components of heavy metals $(\mathrm{Cd}, \mathrm{Zn}, \mathrm{Cu}, \mathrm{Pb})$ budgets in the Lot-Garonne fluvial system (France). Appl. Geochem. 19, 769-786. 
Benoit, G., Rozan, T.F., 1999. The influence of size distribution on the particle concentration effect and trace metal partitioning in rivers. Geochim. Cosmochim. Acta 61 (10), 113-127.

Benoit, G., Oktay-Marshall, S.D., Cantu II, A., Hood, E.M., Coleman, C.H., Corapcioglu, M.O., Santschi, P.H., 1994. Partitioning of $\mathrm{Cu}, \mathrm{Pb}, \mathrm{Ag}, \mathrm{Zn}, \mathrm{Fe}, \mathrm{Al}$, and $\mathrm{Mn}$ between filter-retained particles and solution in six Texas estuaries. Mar. Chem. 45, 307336.

Bourennane, H., Douay, F., Sterckeman, T., Villanneau, E., Ciesielski, H., King, D., Baize, D., 2010. Mapping of anthropogenic trace elements inputs in agricultural topsoil from Northern France using enrichment factors. Geoderma 157, 165174.

Brunel, C., Munoz, M., Probst, A., 2003. Remobilisation of $\mathrm{Zn}$ and $\mathrm{Pb}$ in a mountain stream contaminated by mining wastes during a moderate flood event (Ariège, France). J. Phys. IV 107, 233-236.

Bur, T., 2008. Impact anthropique sur les éléments traces métalliques dans les sols agricoles de Midi-Pyrénées. Implications en terme de limites et de charges critiques. PhD thesis, Université de Toulouse, INPT, pp. 329.

Bur, T., Crouau, Y., Bianco, A., Gandois, L., Probst, A., 2012. Toxicity of $\mathrm{Pb}$ and of $\mathrm{Pb} /$ $\mathrm{Cd}$ combination on the springtail Folsomia candida in natural soils: reproduction, growth and bioaccumulation as indicators. Science of the Total Environment 414, 187-197.

Coynel, A., Schäfer, J., Blanc, G., Bossy, C., 2007. Scenario of particulate trace metal and metalloid transport during a major flood event inferred from transient geochemical signals. Appl. Geochem. 22, 821-836.

Duan, N., 1983. Smearing estimate: a non-parametric retransformation method. J. Am. Stat. Assoc. 78, 605-610.

Elbaz-Poulichet, F., Braungardt, C., Achterberg, E., Morley, N., Cossa, D., Beckers, J.M., Nomérange, P., Cruzado, A., Leblanc, M., 2001. Metal biogeochemistry in the Tinto-Odiel rivers (Southern Spain) and in the Gulf of Cadiz: a synthesis of the results of TOROS project. Cont. Shelf Res. 21 (18-19), 1961-1973.

Ferrant, S., Laplanche, C., Durbe, G., Probst, A., Dugast, P., Durand, P., Sanchez-Perez, J.M., Probst, J.L., 2012. Continuous measurement of nitrate concentration in a highly event-responsive agricultural catchment in south-west of France: is the gain of information useful? Hydrol. Process.. http://dx.doi.org/10.1002/ hyp.9324.

Gaeiro, D.M., Probst, J.-L., Depetris, P.J., Bidart, S.M., Leleyter, L., 2003. Iron and other transition metals in Patagonian riverborne and windborne materials: geochemical control and transport to the southern South Atlantic Ocean. Geochim. Cosmochim. Acta 67 (19), 3603-3623.

Gandois, L., Probst, A., Dumat, C., 2010. Modeling trace metal extractability and solubility using soil properties in French forest soils. Eur. J. Soil Sci. 61, 271-286.

Guégen, C., Dominik, J., 2003. Partitioning of trace metals between particulate, colloidal and truly dissolved fractions in a polluted river: the Upper Vistula River (Poland). Appl. Geochem. 18, 457-470.

Gundersn, P., Steinnes, E., 2003. Influence of pH and TOC concentration on Cu, Zn, Cd and Al speciation in rivers. Water Res. 37, 307-318.

Helsen, D.R., Hirsch, R.M., 2002. Statistical Methods in Water Research. Elsevier, Amsterdam, pp. 79.

Hernandez, L., Probst, A., Probst, J.L., Ulrich, E., 2003. Heavy metal distribution in some French forest soils: evidence for atmospheric contamination. Sci. Total Environ. 312, 195-219.

Hissler, C., Probst, J.L., 2006. Impact of mercury atmospheric deposition on soils and streams in a mountainous catchment (Vosges, France) polluted by chlor-alkali industrial activity: the important trapping role of the organic matter. Sci. Total Environ. 361 (1-3), 163-178.

Jiang, H., Li, T., Han, X., Yang, X., He, Z., 2011. Effects of pH and low molecular weight organic acids on competitive adsorption and desorption of cadmium and lead in paddy soils. Environ. Monit. Assess. 184 (10), 6325-6335.

Leleyter, L., Probst, J.L., 1999. A new sequential extraction procedure for the speciation of particulate trace elements in river sediments. Int. J. Environ. Anal. Chem. 73, 109-128.

Ma, Y.B., Lombi, E., Oliver, I.W., Nolan, A.L., McLaughlin, M.J., 2006. Long-term aging of copper added to soils. Environ. Sci. Technol. 40, 6310-6317.

McLennan, S.M., 1989. Rare earth elements in sedimentary rocks: influence of provenance and sedimentary processes. In: Lippin, B.R., McKay, G.A. (Eds.), Reviews in Mineralogy. Geochemistry and Mineralogy of Rare Earth Elements, vol. 21. Mineral. Soc. Am., Washington, pp. 169-200.

Miller, C.V., Foster, G.D., Majedi, B.F., 2003. Baseflow and stormflow metal fluxes from two small agricultural catchments in the Coastal Plain of the Chesapeak Bay Basin, United States. Appl. Geochem. 18, 483-501.
Mordvet, J.J., Osborn, G., 1982. Studies on the chemical form of cadmium contaminants in phosphate fertilizers. Soil Sci. 134, 185-192.

N'Guessan, Y.M., 2008. Dynamique des elements traces dans les eaux de surface des bassins versants agricoles de Gascogne. PhD thesis, Université de Toulouse, INPT, pp. 213.

N'Guessan, Y.M., Probst, J.L., Bur, T., Probst, A., 2009. Trace elements in stream bed sediments from agricultural catchments (Gascogne region, S-W France): Where do they come from? Sci. Total Environ. 407 (8), 2939-2952.

Nicholson, F.A., Smith, S.R., Alloway, B.J., Carlton-Smith, C., Chambers, B.J., 2003. An inventory of heavy metals inputs to agricultural soils in England and Wales. Sci. Total Environ. 378, 293-305.

Nziguheba, G., Smolders, E., 2008. Inputs of trace metals in agricultural soils via phosphate fertilizers in European countries. Sci. Total Environ. 390 (1), 53-57.

Oliver, M.A., 1997. Soil and human health: a review. Eur. J. Soil Sci. 48, 573-592.

Ollivier, P., Radakovitch, O., Hamelin, B., 2011. Major and trace element partition and fluxes in the Rhône River. Chem. Geol. 285 (1-4), 15-31.

Perrin, A.S., Probst, A., Probst, J.-L., 2008. Impact of nitrogenous fertilizers on carbonate dissolution in small agricultural catchments: implications for weathering $\mathrm{CO}_{2}$ uptake at regional and global scales. Geochim. Cosmochim. Acta 72 (13), 3105-3123.

Probst, J.L., 1986. Dissolved and suspended matter transported by the Girou River (France): mechanical and chemical erosion rates in a calcareous molasse basin. Hydrol. Sci. 31 (1), 61-79.

Probst, J.L., Bazerbachi, A., 1986. Transports en solution et en suspension par la Garonne supérieure. Sciences Géologiques Bull. 39 (1), 79-98.

Probst, J.L., Tardy, Y., 1985. Fluctuations hydroclimatiques du bassin d'Aquitaine au cours des 70 dernières années: Revue de Géologie Dynamique et Géographie Physique, vol. 56, pp. 59-76.

Roussiez, V., Ludwig, W., Radakovitch, O., Probst, J.L., Monaco, A., Charrière, B., Buscail, R., 2011. Fate of metals in coastal sediments of a Mediterranean flooddominated system: an approach based on total and labile fractions. Estuar. Coast. Shelf Sci. 92, 486-495.

Roussiez, V., Heussner, S., Ludwig, W., Radakovitch, O., Durrieu de Madron, X., Guieu, C., Probst, J.-L., Monaco, A., Delsaut, N., 2012. Impact of oceanic floods on particulate metal inputs to coastal and deep-sea environments: a case study in the NW Mediterranean Sea. Cont. Shelf Res. 45, 15-26.

Song, Y., Choi, M.S., 2009. REE geochemistry of fine-grained sediments from major rivers around the Yellow Sea. Chem. Geol. 266 (3-4), 328-342.

Sparks, D.L., 1995. Environmental Soil Chemistry. Academic Press, New York.

Sternbeck, J., Skei, J., Verta, M., Östlund, P., 1999. Mobilisation of Sedimentary Trace Metals Following Improved Oxygen Conditions: An Assessment of the Impact of Lowered Primary Productivity on Trace Metal Cycling in the Marine Environment. In: Nordic Council of Minister Eds. TemaNord, vol. 594, 1999, $65 \mathrm{pp}$.

Sutherland, R.A., 2000. Bed sediment-associated trace metals in an urban stream, Oahu, Hawaii. Environ. Geol. 39, 611-627.

Syvitski, J.P.M., Morehead, M., 1999. Estimating river-sediment discharge to the ocean: application to the Eel margin, Northern California. Mar. Geol. 154, 1328.

Taghavi, L., Probst, J.L., Merlina, G., Marchand, A.L., Durbe, G., Probst, A., 2010. Flood event impact on pesticide transfer in a small agricultural catchment (Montoussé at Aurade, south west France). Int. J. Environ. Anal. Chem. 90 (36), 390-405.

Taghavi, L., Merlina, G., Probst, J.L., 2011. The role of storm flows in concentration of pesticides associated with particulate and dissolved fractions as a threat to aquatic ecosystems. Case-study: The Agricultural Watershed of Save River (Southwest of France). Knowledge Management of Aquatic Ecosystems, vol. 400 (6), $11 \mathrm{pp}$.

Xu, Z., Lim, D., Choi, J., Yang, S., Jung, H., 2009. Rare earth elements in bottom sediments of major rivers around the Yellow Sea: implications for sediment provenance. Geo-Mar. Lett. 29, 291-300.

Xue, H., Sigg, L., Gächter, R., 2000. Transport of $\mathrm{Cu}, \mathrm{Zn}$ and $\mathrm{Cd}$ in a small agricultural catchment. Water Res. 34, 2558-2568.

Zhang, J., 1999. Heavy metal compositions of suspended sediments in the Changjiang (Yangtze River) estuary: significance of riverine transport to the ocean. Cont. Shelf Res. 19 (12), 1521-1543.

Zwolsman, J.J.G., van Eck, G.T.M., van der Weijden, C.H., 1997. Geochemistry of dissolved trace metals (cadmium, copper, zinc) in the Scheldt estuary, southwestern Netherlands: impact of seasonal variability. Geochim. Cosmochim. Acta 61, 1635-1652. 